\title{
Removal of Manganese from Well-Water on Pasuruan, East Java, Indonesia Using Fixed Bed Cation Exchanger and Prediction of Kinetics Adsorption
}

\author{
Esthi Kusdarini' and Agus Budianto ${ }^{2}$ \\ 'Mining Engineering Department, Adhi Tama Surabaya Institute of Technology, Surabaya, Indonesia; \\ esti@itats.ac.id \\ ${ }^{2}$ Chemical Engineering Department, Adhi Tama Surabaya Institute of Technology, Surabaya, Indonesia; \\ budichemical@itats.ac.id
}

\begin{abstract}
Objectives: Testing of a cation exchanger based water treatment apparatus and an Amberlite IR 120 Na resin medium to reduce the manganese content in the well-water is proposed. Methods/Statistical Analysis: Testing was done by wellwater treatment in a fixed bed cation exchanger in continuous flow. The variables used were the resin mass and flow rate and its effect on the manganese concentration in the outflow of the equipment. Manganese content was analyzed by Atomic Absorption Spectrophotometry (AAS) method. The isothermal adsorption equation was tested by the Freundich and Langmuir equations. Findings: The result of this research showed Amberlite resin IR $120 \mathrm{Na}$ adsorbed manganese ion was about 96.3-98.9\%; the optimal resin mass about 20 grams with a flow rate about 0.04 L.s-1 when viewed from an economic point. Resin absorption power to manganese increases with decreasing flow rate and increasing resin mass. Freundlich equation with constant $\mathrm{n}=0.6539$ and $\mathrm{K}_{\mathrm{f}}=4.6644$ with correlation coefficient 0.7957 . Langmuir equation with a constant $A_{s}=-0.0927$ and $K_{b}=-6.3820$ with a correlation coefficient -0.4314 . Application/Improvements: Cation exchanger using Amberlite IR 120 Na resin media capable of remove manganese in well-water with efficiency $>96 \%$ and resin can be regenerated again.-
\end{abstract}

Keywords: Cation Exchange, Isothermal Adsorption, Removal Manganese, Spectrophotometry Method, Water Treatment

\section{Introduction}

The content of ions and elements in ground water have varies for different locations. They can be affected by water processing, soil erosion processing, and anthropogenic sources (for example mining industrial, smelting of iron ore, steel, and iron production, or waste water disposal ${ }^{1-2}$. The content of manganese in water ${ }^{3}$ is about 0.0004 until $0.2 \mathrm{mg} . \mathrm{L}^{-1}$. Based on World Health Organization, the content of manganese in the water ${ }^{4}$ has maximum about $0.1 \mathrm{mg} . \mathrm{L}^{-1}$. Generally, in Indonesia there is Well-water which consists of manganese above the maximum water requirements. Based on Regulation of Indonesia Health Minister ${ }^{5}$, the standardize of clean water contains maximum manganese about $0.5 \mathrm{mg} \cdot \mathrm{L}^{-1}$. Well-water which containing large enough of manganese, the water colour will be blackish yellow after contact with air and smelling. This water will make blackish spotted on the clothes if the people use this water to wash the clothes ${ }^{6}$. This water also makes black spotted to the toiletries. Manganese shape in the water usually Mn (II) labile, particulate Mn (IV) and Mn (IV) hydroxide ${ }^{7}$. Manganese is a powerful oxidizing agent. If the water contains manganese into the body, this water has a potential to interfere human healthy. There are few effects which affected by manganese in the water, like disorder of mucous membranes, esophagus, manganism, or Parkinson disease, bone disorder, osteoporosis, perthe's disease, cardiovascular disorders, liver, reproductive disorders and mental development, hypertension, hepatitis, posthepatic cirrhosis, hair color changes, obe-

${ }^{*}$ Author for correspondence 
sity, skin problems, cholesterol, neurological symptoms, and epilepsy ${ }^{8} .9$. Manganese toxicity usually progressive and irreversible, the discovery of Mn exposure biomarker is growing imperatively ${ }^{10}$.

There are few procedures are able to do to decrease the content of toxic substances in water. There are precipitations $s^{\frac{11}{}}$, adsorption ${ }^{\frac{12}{2}}$, membrane process $\frac{13-15}{}$, and electrolytic method ${ }^{16}$. Pretreatment in the adsorption process is aeration or oxidation process. Pretreatment in adsorption process is aeration or oxidation process. In aeration process $\mathrm{Mn}$ ions change into $\mathrm{Mn}$ ions with higher oxidation numbers and form precipitate. Furthermore, this precipitate is filtered by sedimentation process or filtration process. If the content of manganese is high enough, it can be used as ion exchanger process.

Several researchers have proven that exchanger ions were good enough to remove heavy metals and toxic materials in the water ${ }^{17}$. The advantages of exchanger ions are saturated resin that can be regenerated and water flow systems during flexible process, either batch or continuous $^{18}$. In exchanger ions can be used resin from natural or synthetic $\frac{19-21}{}$. Al-Wakeel et al in 2015 examined the efficiency of manganese removal from solution using chitosan resin (G@Chs). The processing was done by batch system. Adsorption was optimal in $\mathrm{pH} 6$ and the contact time was 150 minutes ${ }^{22}$. The research conducted by Wakeel et al $\underline{22}$ got adsorption efficiency of manganese that was high enough (96.4\%), but the research object was artificial sample, not Well-water. This research would refine the previous research that was the use of Amberlite resin IR120 $\mathrm{Na}$ which has been shown adsorption efficiency and high enough cation exchange for lead $(\mathrm{Pb})$, which was about $99 \%$ in batch system with contact time about 4 hours ${ }^{23}$. This research would also refine the previous research which used Well-water sample taken from Kebonagung, Purworejo sub-district, Pasuruan, East Java, Indonesia.

\section{Materials and Methods}

\subsection{Materials and Resin Characteristics}

The materials used were well-water, Amberlite resin IR $120 \mathrm{Na}$, and aquadest. Well-water sample was taken from Kebonagung, Purworejo sub-district, Pasuruan, East Java, Indonesia and the well depth was 42 meters. Amberlite IR $120 \mathrm{Na}$ is strong acid cation exchange resin with the chemical formula $\left[\mathrm{SO}_{2} \mathrm{NaC}_{6} \mathrm{H}_{4} \mathrm{CHCH}_{2}\right]$
$\mathrm{CHCH}_{2} \mathrm{C}_{6} \mathrm{H}_{4} \mathrm{CHCH}_{2}$. Properties of Amberlite resin IR $120 \mathrm{Na}$ shown in the Table 1.

Table 1. Properties of amberlite resin IR $120 \mathrm{Na}$

\begin{tabular}{|c|c|}
\hline Physical Form & Amber spherical beads \\
\hline Matrix & $\begin{array}{l}\text { Styrene divinylbenzene } \\
\text { copolymer }\end{array}$ \\
\hline Functional group & Sulfonate \\
\hline Ionic form as shipped & $\mathrm{Na}^{+}$ \\
\hline Total exchange capacity & $\geq 2.00 \mathrm{eq} / \mathrm{L}\left(\mathrm{Na}^{+}\right.$form $)$ \\
\hline $\begin{array}{l}\text { Moisture holding capacity } \\
\text { Shipping weight }\end{array}$ & $\begin{array}{l}45 \text { to } 50 \%\left(\mathrm{Na}^{+} \text {form }\right) \\
840 \mathrm{~g} / \mathrm{L}\end{array}$ \\
\hline $\begin{array}{l}\text { Particle Size } \\
\text { Uniformity coefficient } \\
\text { Harmonic mean size } \\
\text { Maximum reversible } \\
\text { swelling }\end{array}$ & $\begin{array}{l}\leq 1.9 \\
0.600 \text { to } 0.800 \mathrm{~mm}<0.300 \\
\operatorname{mm} 2 \% \max \\
\mathrm{Na}^{+} \rightarrow \mathrm{H}^{+} \leq 11 \%\end{array}$ \\
\hline
\end{tabular}

\subsection{Tools and Installation Management}

The tools used were pump, plastic jug, water container, porcelain cup, and analytical balance. The processing installation is shown in Figure 1.

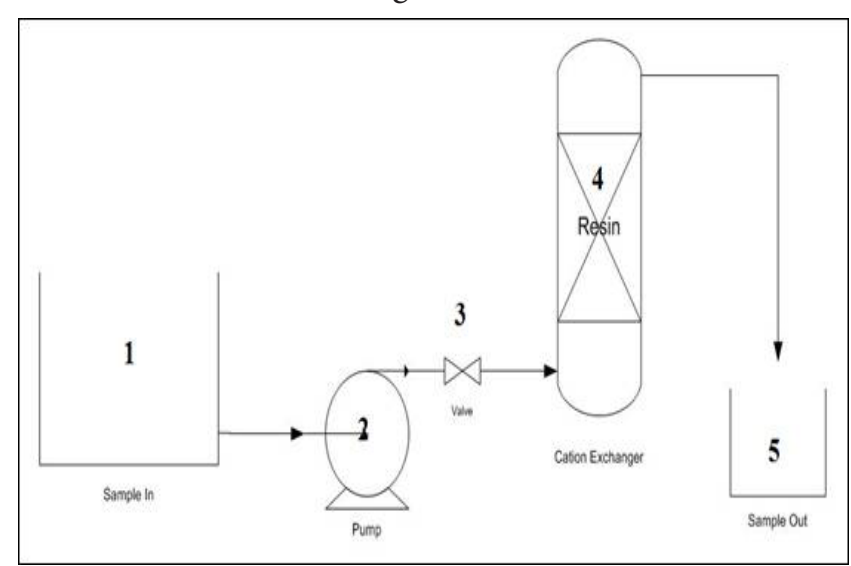

Figure 1. Installation of cation exchanger process.

Explanation:

1. Water container.

2. Pump.

3. Valve.

4. Resin reservoir (Fixed Bed). and

5. Water-storage shelter.

The high pool fixed bed ion exchange was $30 \mathrm{~cm}$, the diameter was 4 inch, and screen strainer was 60 meshes.

\subsection{Research Procedure}

This research procedure was started from taking the sample, analyzing of initially water quality, weighing of resin, 
measuring of $\mathrm{pH}$ and Well-water temperature, processing of Well-water, analyzing of water processed, managing of data analysis result, and formulating of Freundlich and Langmuir equation. The weight of resin were 20 grams, 60 grams, 80 grams, and 100 grams, each of them was 3 pieces. In this research, the processing system in a continuously was using $302^{\circ} \mathrm{K}$ water temperature. The variables used were resin mass and flow rate. There were four resin mass variables; 20 grams, 60 grams, 80 grams, 100 grams. For flow rate, there were three variables, such as $0.02 \mathrm{~L} . \mathrm{s}$ '; $0.03 \mathrm{~L} . \mathrm{s}^{-1}$; and $0.04 \mathrm{~L} . \mathrm{s}^{-1}$. The analyzing of manganese degree in the water was using atomic absorption spectrophotometry method.

\subsection{Manganese Removal}

Amberlite resin IR $120 \mathrm{Na}$ has been removed the manganese by absorption and ions exchanger process. The efficiency ( $\eta$ ) of Amberlite resin $120 \mathrm{Na}$ in manganese removal was calculated with eq. (1).

$$
\eta=\frac{\mathrm{C}_{\mathrm{i}}-\mathrm{C}_{0}}{\mathrm{C}_{\mathrm{i}}} \times 100 \%
$$

$\eta$ is resin efficiency in manganese removal (\%), $C_{i}$ is manganese degree in the Well-water before processing (mg.L $\mathrm{L}^{-1}$ ), and $\mathrm{C}_{\mathrm{o}}$ is manganese degree in the Well-water after processing $\left(\mathrm{mg} \cdot \mathrm{L}^{-1}\right)$.

\subsection{Isothermal Absorption}

Absorption processes through ions exchanger reaction mechanism, physical adsorption, electrolytes molecule adsorption, the formation of complexes between central ions and functional groups, and the formation of hydrates in the surface or in the pores of the adsorbent. The amounts of metal which can be absorbed by resin are the function from two concentrates; metal and temperature. The amount of Mn absorbed is determined as concentration function in the constant temperature. It can be explained in the isothermal adsorption equation, between Freunlich and Langmuir. Freundlich isothermal equations were used to describe the resin adsorption characteristics which used in solution or waste water treatment $\underline{24}$.

The adsorption power of Amberlite resin 1RR $120 \mathrm{Na}$ to $\mathrm{Mn}$ can be described in the equations of Freundlinch and Langmuir. These two equations described the effi- ciency of resin adsorption to $\mathrm{Mn}$ from Well-water. In this study, it is not known exactly the oxidation of manganese ions in the water. However, most manganese in the natural water is in the form of mainly Mn (II) ions, particulate Mn (IV), and Mn (IV) hydroxide (2). Manganese ions adsorption in the surface of Amberlite resin IR $120 \mathrm{Na}$ can be evaluated using equation isotherm adsorption. Water treatment process in this study was using continue system. Therefore, the data taken to isotherm adsorption evaluate was the smallest flow rate, was 0.02 L.s- 1 with the assumption the condition processes have had steady state. Ishotermal adsorption is a system in balance condition between manganese concentrate in the Well water and manganese concentrate in resin at a certain temperature ${ }^{25}$. Isotherm absorption is able to give important information about absorption strength and maximum absorption capacity as it helps predict the condition and predict the operating experiment condition is more optimal. The characteristic of isotherm absorption of Amberlite resin $120 \mathrm{Na}$ to manganese can be evaluated using Freundlich and Langmuir equation.

\subsection{Freundlich Equation}

Freundlich Equation is shown in (2).

$$
\begin{aligned}
\frac{\mathrm{x}}{\mathrm{m}}=\mathrm{K}_{\mathrm{f}} \times \mathrm{C}_{\mathrm{e}}^{1 / \mathrm{n}} & \frac{\mathrm{x}}{\mathrm{m}}=\mathrm{K}_{\mathrm{f}} \times \mathrm{C}_{\mathrm{e}}^{1 / \mathrm{n}}
\end{aligned}
$$

$\frac{x}{m}$ Is Mn amount was absorbed per unit resin mass (mg.L

$\left.{ }^{1} \cdot \mathrm{g}^{-1}\right)$, Ce is $\mathrm{Mn}$ concentration in adsorbate after the desorption process $\left(\mathrm{mg} \cdot \mathrm{L}^{-1}\right), \mathrm{K}_{\mathrm{f}}$ and $\mathrm{n}$ are empirical constanta. Constants $\mathrm{K}_{\mathrm{f}}$ and $\mathrm{n}$ can be searched by eq. (3).

$$
\log \frac{\mathrm{x}}{\mathrm{m}}=\log \mathrm{K}_{\mathrm{f}}+\frac{1}{\mathrm{n}} \log \mathrm{C}_{\mathrm{e}}
$$

\subsection{Langmuir Equation}

Langmuir isothermal equation is shown in (4).

$$
\frac{\mathrm{c}}{\mathrm{q}}=\frac{1}{\mathrm{~K}_{\mathrm{b}} \mathrm{A}_{\mathrm{s}}}+\frac{\mathrm{c}}{\mathrm{A}_{\mathrm{s}}}
$$

$\mathrm{A}_{\mathrm{s}}$ and $\mathrm{K}_{\mathrm{b}}$ are coefficient, $\mathrm{q}$ is $\mathrm{Mn}$ weight which adsorbed per unit resin mass $\left(\mathrm{mg} \cdot \mathrm{L}^{-1} \cdot \mathrm{g}^{-1}\right)$, and $\mathrm{c}$ is Mn concentration in the Well-water after absorbed $\left(\mathrm{mg} \cdot \mathrm{L}^{-1}\right)$. 


\section{Result and Discussion}

This study is studied about the effect the changing of resin mass and flow rate to the efficiency of Amberlite resin IR $120 \mathrm{Na}$ for decreasing Mn content from well water. Besides, this study would study about isotherm adsorption kinetics of Amberlite resin IR $120 \mathrm{Na}$ to manganese contained in well-water.

\subsection{Beginning Analysis of Well Water}

Well water that would be processed into clean water analyzed its characteristics based on parameters in Regulation of Indonesia Health Minister ${ }^{5}$. The result of the initial analysis of the Well-water samples are presented in Table 2 shows that the maximum manganese content in clean water is $0.5 \mathrm{mg} / \mathrm{l}$, whereas the manganese content of well water is $2.72 \mathrm{mg} / \mathrm{l}$. this proves that manganese content in well water is not yet qualified as clean water.

Table 2. Comparison of well-water specifications to clean water specifications

\begin{tabular}{lll}
\hline \multicolumn{1}{c}{ Parameter } & \multicolumn{1}{c}{ Degree } & \multicolumn{1}{c}{ Maximally* } \\
\hline Smell & No smell & No smell \\
Taste & Normal & Normal \\
Temperature & $26.1^{\circ} \mathrm{C}$ & Water Temperature $\pm 3^{\circ} \mathrm{C}$ \\
TDS & $433 \mathrm{mg} / \mathrm{L}$ & $1500 \mathrm{mg} / \mathrm{L}$ \\
Turbidity & $6.73 \mathrm{NTU}$ & $25 \mathrm{NTU}$ \\
Colour & $0 \mathrm{Pt} / \mathrm{Co}$ & $50 \mathrm{Pt} / \mathrm{Co}$ \\
$\mathrm{pH}$ & 7.64 & $6.5-9.0$ \\
$\mathrm{As}$ & $<0.00006 \mathrm{mg} / \mathrm{L}$ & $0.05 \mathrm{mg} / \mathrm{L}$ \\
$\mathrm{Fe}$ & $0.87 \mathrm{mg} / \mathrm{L}$ & $1 \mathrm{mg} / \mathrm{L}$ \\
$\mathrm{F}$ & $0.46 \mathrm{mg} / \mathrm{L}$ & $1.5 \mathrm{mg} / \mathrm{L}$ \\
$\mathrm{Cd}$ & $<0.001 \mathrm{mg} / \mathrm{L}$ & $0.005 \mathrm{mg} / \mathrm{L}$ \\
$\mathrm{CaCO} 3$ & $332 \mathrm{mg} / \mathrm{L}$ & $500 \mathrm{mg} / \mathrm{L}$ \\
$\mathrm{Cl}-$ & $40 \mathrm{mg} / \mathrm{L}$ & $600 \mathrm{mg} / \mathrm{L}$ \\
$\mathrm{Cr} 6+$ & $<0.026 \mathrm{mg} / \mathrm{L}$ & $0.05 \mathrm{mg} / \mathrm{L}$ \\
$\mathrm{Mn}$ & $2.72 \mathrm{mg} / \mathrm{L}$ & $0.5 \mathrm{mg} / \mathrm{L}$ \\
$\mathrm{Nitrate}$ & $0.15 \mathrm{mg} / \mathrm{L}$ & $10 \mathrm{mg} / \mathrm{L}$ \\
$\mathrm{Nitrite}$ & $<0.01 \mathrm{mg} / \mathrm{L}$ & $1 \mathrm{mg} / \mathrm{L}$ \\
$\mathrm{Hg}$ & $<0.000008 \mathrm{mg} / \mathrm{L}$ & $0.001 \mathrm{mg} / \mathrm{L}$ \\
$\mathrm{Se}$ & $<0.00007 \mathrm{mg} / \mathrm{L}$ & $0.01 \mathrm{mg} / \mathrm{L}$ \\
$\mathrm{Zn}$ & $0.072 \mathrm{mg} / \mathrm{L}$ & $15 \mathrm{mg} / \mathrm{L}$ \\
$\mathrm{CN}$ & $<0.01 \mathrm{mg} / \mathrm{L}$ & $0.1 \mathrm{mg} / \mathrm{L}$ \\
$\mathrm{SO} 4$ & $<4.2 \mathrm{mg} / \mathrm{L}$ & $400 \mathrm{mg} / \mathrm{L}$ \\
$\mathrm{Pb}$ & $<0.002 \mathrm{mg} / \mathrm{L}$ & $0.05 \mathrm{mg} / \mathrm{L}$ \\
& &
\end{tabular}

\begin{tabular}{lll} 
Surfactant & $<0.05 \mathrm{mg} / \mathrm{L}$ & $0.5 \mathrm{mg} / \mathrm{L}$ \\
Organic & $<7.6 \mathrm{mg} / \mathrm{L}$ & $10 \mathrm{mg} / \mathrm{L}$ \\
Coliform & 9 Col. $/ 100 \mathrm{~mL}$ & $10 \mathrm{Col} . / 100 \mathrm{~mL}$ \\
\hline
\end{tabular}

${ }^{*}$ Regulation of Indonesia Health Minister ${ }^{5}$

\subsection{The Efficiency of Amberlite Resin IR $120 \mathrm{Na}$}

The analysis of manganese content in Well water which has been processed using Amberlite resin IR $120 \mathrm{Na}$ with two variables; resin mass and flow rate $(\mathrm{Q})$ described in Table 3 showed manganese content from Well water which has been processed with Amberlite resin IR 120 $\mathrm{Na}$. Table 3 presents manganese content from Well water treated using Amberlite resin IR $120 \mathrm{Na}$ has fulfilled the requirements of clean water based on Minister of Health Regulation Number 32/2017. The ability of Amberlite resin IR $120 \mathrm{Na}$ in doing manganese absorption in the water counted from efficiency formula in equation(1). The efficiency of Amberlite resin IR $120 \mathrm{Na}$ in decreasing manganese shown in Table 4.

Table 3. Analysis of manganese content from wellwater after processed with amberlite resin IR $120 \mathrm{Na}$

\begin{tabular}{cccc}
\hline \multirow{2}{*}{$\begin{array}{c}\text { Resin } \\
\text { Mass (g) }\end{array}$} & \multicolumn{3}{c}{ Manganese Content $\left(\mathbf{m g . L ^ { - 1 }}\right)$} \\
\cline { 2 - 4 } & $\mathbf{Q 1 = 0 . 0 2} \mathbf{~ L . s}^{-\mathbf{1}}$ & $\mathbf{Q 2}=\mathbf{0 . 0 3} \mathbf{~ L . s}^{-1}$ & $\mathbf{Q 3}=\mathbf{0 . 0 4} \mathbf{~ L . s ~}^{-1}$ \\
\hline 20 & 0.07 & 0.07 & 0.1 \\
60 & 0.06 & 0.06 & 0.09 \\
80 & 0.05 & 0.05 & 0.09 \\
100 & 0.03 & 0.03 & 0.09 \\
\hline
\end{tabular}

Table 4. The efficiency of Amberlite resin IR $120 \mathrm{Na}$ in doing manganese absorption in well-water

\begin{tabular}{|c|c|c|c|}
\hline \multirow{2}{*}{$\begin{array}{l}\text { Resin } \\
\text { mass (g) }\end{array}$} & \multicolumn{3}{|c|}{ Efficiency of Amberlite resin IR $120 \mathrm{Na}(\%)$} \\
\hline & $\mathrm{Q} 1=0.02 \mathrm{~L} . \mathrm{s}^{-1}$ & $\mathrm{Q} 2=0.03{\mathrm{~L} . \mathrm{s}^{-1}}^{-1}$ & $\mathrm{Q3}=0.04 \mathrm{~L} . \mathrm{s}^{-1}$ \\
\hline 20 & 97.43 & 97.44 & 96.32 \\
\hline 60 & 97.79 & 97.79 & 96.69 \\
\hline 80 & 98.16 & 98.16 & 96.69 \\
\hline 100 & 98.90 & 98.90 & 96.69 \\
\hline
\end{tabular}

Table 4 has shown manganese degree from Well water after processed with resin and the variables of resin mass and flow rate. Table 4 presented flow rate $0.02{\mathrm{~L} . \mathrm{s}^{-1}}$ resin efficiency between $97.43-98.90 \%$; in flow rate $0.03 \mathrm{~L} . \mathrm{s}^{-1}$ resin efficiency among $97.44-98.90 \%$; and in flow rate 0.04 L.s $^{-1}$ resin efficiency about $96.32-96.69 \%$. 
Efficiency of Amberlite resin IR $120 \mathrm{~N}$ a adsorption to manganese with resin mass and flow rate variables. This research was learning about the influence of flow rate to $\mathrm{Mn}$ content in the water treatment and the efficiency of resin adsorption. There were three flow rate variables used; $0.02 \mathrm{~L} . \mathrm{s}^{-1} ; 0.03 \mathrm{~L} . \mathrm{s}^{-1}$; and $0.04 \mathrm{~L} . \mathrm{s}^{-1}$. Table 3 showed well water skipped by resin in the pool with continuous system has met the requirements of clean water based on Regulation of the Minister of Health Number $32 / 2017$. The lower flow rate got, the lower the content of ion $\mathrm{Mn}^{2+}$ in the water treatment got. It proved the lower flow rate got, the higher the efficiency of resin adsorption to $\mathrm{Mn}$ was higher. Resin efficiency to flow rate $0.02 \mathrm{~L} . \mathrm{s}^{-1}$ and 0.03 L.s ${ }^{-1}$ were same, about $97,4-98,9 \%$. The correlation between the resin mass and efficiency of resin for the flow rate $0.02 \mathrm{~L} . \mathrm{s}^{-1}, 0.03 \mathrm{~L} . \mathrm{s}^{-1}, 0.04 \mathrm{~L} . \mathrm{s}^{-1}$ was about 0.9535 , 0.9264 , and 0.8783 . The highest correlation was achieved at the flow rate $0.02 \mathrm{~L} \cdot \mathrm{s}^{-1}$.

This study was also learning the influence of resin mass to manganese content of water treatment and the efficiency of resin adsorption. There were four resin mass variables used. They were 20 grams, 60 grams, 80 grams, and 100 grams. Table 3 showed manganese content in the water treatment has been requirement of clean water based on Minister of Health Regulation Number 32 /2017. The larger the resin mass, the lower the manganese content of the Well water. In flow rate 0.02 L.s- 1 and 0.03 L.s-1, resin mass optimal was 60 grams. Figure 1 presented flow rate 0.02 L.s- 1 dan 0.03 L.s- 1 , the higher resin mass, the higher the efficiency of resin absorption to $\mathrm{Mn}$ in the Well water. The efficiency of resin absorption in resin mass condition 100 grams was $98.90 \%$. In flow rate 0.04 L.s-1, the higher resin mass, the higher the efficiency of resin adsorption to $\mathrm{Mn}$, but the mass of 60 grams, there was no more increases the efficiency of adsorption. Optimal resin efficiency at 60 grams was $96.69 \%$. Table 4 showed that the correlation between the flow rate and efficiency of resin for the resin mass $20 \mathrm{~g}, 60 \mathrm{~g}, 80 \mathrm{~g}, 100$ g was about $0.8660,0.8660,0.9993,0.9387$. The highest correlation was achieved at the resin mass $80 \mathrm{~g}$.

The biggest resin efficiency was in resin mass condition 100 grams with flow rate $0.02 \mathrm{~L} . \mathrm{s}^{-1}$ and $0.03 \mathrm{~L} . \mathrm{s}^{-1}$. That was $98.9 \%$. It proves if the efficiency of Amberlite resin IR $120 \mathrm{Na}$ decreases Mn content in the Well water is higher than the efficiency of chitosan resin which modified with glycine (G@Chs) ${ }^{22}$ in decreasing Mn content from synthetic sample, about $96.4 \%$.

\subsection{Isothermal Absorption}

The absorption power of Amberlite resin IR $120 \mathrm{Na}$ to Mn can be described in Freundlich and Langmuir equation. The both equation describe the efficiency of resin absorption to $\mathrm{Mn}$ from Well-water. Freundlich equation is shown in eq. (2) and (3). The graphic to describe Freundlich equation is in Figure 2.

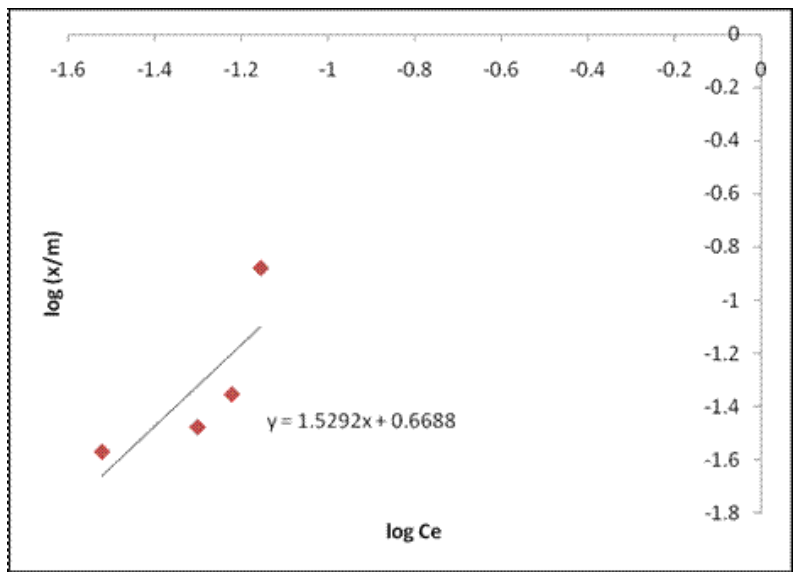

Figure 2. $\log (\mathrm{x} / \mathrm{m})$ and $\log \mathrm{C}_{\mathrm{e}}$ in Freundlich equation.

Figure 2 is a graphic connection between $\log (\mathrm{x} / \mathrm{m})$ and $\log$ $\mathrm{C}_{\mathrm{e}}$. Based on eq. (3) and Figure 2 was gotten $(1 / \mathrm{n})=1.5292$ and $n=0.6539$. Whereas, $\log K_{f}=0.6688$ so $K_{f}=4.6644$.

Freundlich equation was obtained from isothermal absorption of Ambrelite resin IR $120 \mathrm{Na}$ to $\mathrm{Mn}$ is:

$$
\frac{\mathrm{x}}{\mathrm{m}}=4.6644 \mathrm{C}_{\mathrm{e}}^{1.5292}
$$

Correlation coefficient from Freundlich equation was about 0.7957 .

Langmuir isothermal equation shown in equation (4). The graphic to describe Langmuir equation shows in Figure 3.

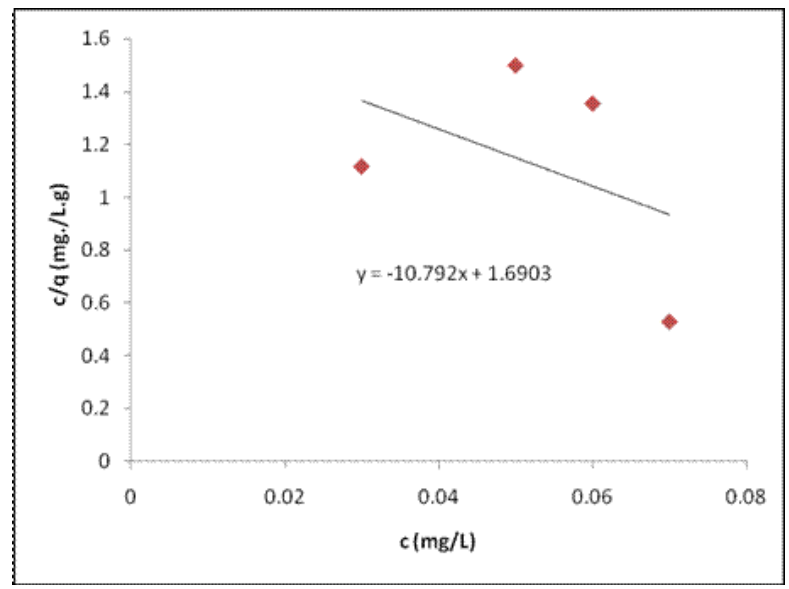

Figure 3. Graphic c/q and $\mathrm{c}$ from Langmuir equation. 
Figure 3 is a connection graphic between c/q and c. Based on eq. (4) and Figure 3 have gotten as $=-0.0927$, while $\mathrm{Kb}=-6.3820$. The Langmuir equation obtained from the isothermall adsorption of Amberlite resin IR $120 \mathrm{Na}$ to Mn was:

$$
\frac{\mathrm{c}}{\mathrm{q}}=1.6903-\frac{\mathrm{c}}{0.0927}
$$

The correlation coefficient Langmuir equation was about -0.4314 .

Graphic fitting c/q and $\mathrm{c}$ from experiments to calculation result based on Freundlich equation and Langmuir equation described in Figure 4.

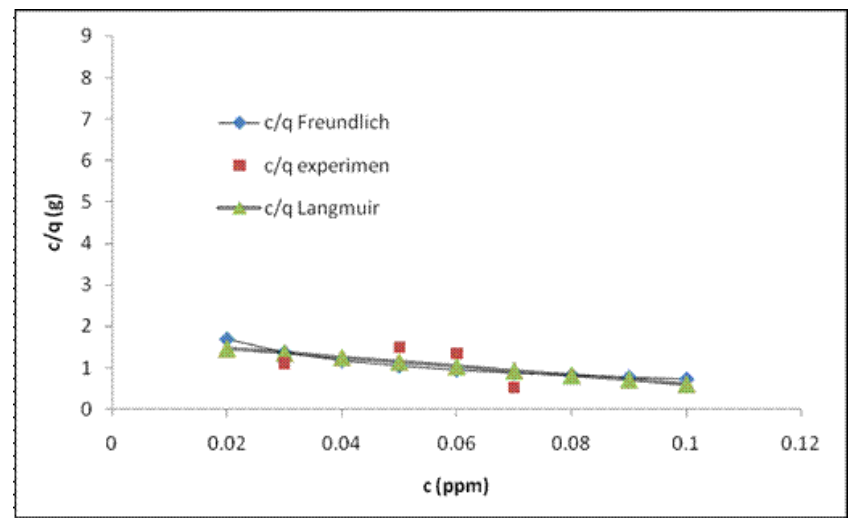

Figure 4. Fitting of $\mathrm{c} / \mathrm{q}$ and $\mathrm{c}$ from experiments to calculation result based on Freundlich and Langmuir equation.

\section{Conclusion}

The result of this study showed Amberlite resin IRT $120 \mathrm{Na}$ was able to produce manganese in the Well-water and for the efficiency was about $96.3-98.9 \%$. Water treatment has filled the requirements of clean water in Indonesia based on the standard of Regulation of Health Minister. Absorption to $\mathrm{Mn}$ (II) can be optimal with resin mass operating system about $20-100$ grams and the flow rate was $0.02-0.04$ $\mathrm{L} / \mathrm{s}$. The lower flow rate and the higher resin mass got, the higher the efficiency of resin absorption to Mn (II) got. The isothermall from Amberlite resin IR $120 \mathrm{Na}$ to Mn(II) in the Well-water was expressed in Freundlich equation with constanta $\mathrm{n}=0.6539$ and $\mathrm{K}_{\mathrm{f}}=4.6644$; whereas when it was expressed in Langmuir equation with constanta $\mathrm{A}_{\mathrm{s}}=-0.0927$ and $\mathrm{K}_{\mathrm{b}}=-6.3820$. Correlation coefficient Freundlinch equation of 0.7957 and it included has a strong correlation. While the Langmuir equation coefficient of -0 , 4314 and it included a moderate correlation.

\section{Acknowledgments}

We thank Chemical Engineering of Teknologi Adhi Tama Surabaya for having provided laboratory facilities for this study.

\section{References}

1. Stefan DS, Meghea I. Mechanism of simultaneous removal of $\mathrm{Ca} 2+, \mathrm{Ni} 2+, \mathrm{Pb} 2+$ and $\mathrm{Al} 3+$ ions from aqueous solutions using Purolite ${ }^{\oplus 930}$ ion exchange resin, Comptes Rendus Chimie. 2014; 17(5):496-502. Crossref.

2. Tobiasz A, Sołtys M, Kurys E, Domagała K, DudekAdamska D, Walas S. Multicomutation flow system for manganese speciation by solid phase extraction and flame atomic absorption spectrometry, Spectrochimica Acta Part B: Atomic Spectrosccopy. 2017; 134:11-6. Crossref.

3. O’Neal SL, Hong L, Fu S, Jiang W, Jones A, Nie LH. Manganese accumulation in bone following chronic exposure in rats: Steady-state concentration and half-life in bone, Toxicology Letters. 2014; 229(1):93-100. Crossref. PMid: 24930841 PMCid:PMC4126163.

4. World Health Organization. Guidelines for drinking-water quality. 4th Edition. WHO Press: Switzerland; 2011. p. 1-24.

5. Indonesia Health Department. Regulation of Indonesia Health Minister number 416/MENKES/PER/IX/1990. Indonesia Health Department, Jakarta; 1990.

6. Kohl PPM, Medlar SJS. Occurrence of manganese in drinking water and manganese control. American Water Works Association: USA; 2006; p. 1-464. PMid: 16040083.

7. Delfino JJ, Lee GF. Chemistry of Manganese in Lake Mendota, Wisconsin, Environmental Science and Technology. 1968; 2(12):1094-100. Crossref.

8. Bidlack WR. Casarett and Doull's Toxicology: The Basic Science of Poisons. 8th Edition. Mc Graw Hill Education/ Exclusively Distd.; 2013. p. 1-1454.

9. Guo Z, Zhang Z, Wang Q, Zhang J, Wang L, Zhang Q, Li $\mathrm{H}$, Wu S. Manganese chloride induces histone acetylation changes in neuronal cells: Its role in manganese-induced damage, Neurotoxicology. 2018 March; 65:255-63. Crossref. PMid:29155171.

10. Ge X, Wang F, Zhong Y, Lv Y, Jiang C, Zhou Y, Li D, Xia B, Su C, Cheng H, Ma Y, Xiong F, Shen Y, Zou Y, Yang X. Manganese in blood cells as an exposure biomarker in manganese-exposed workers healthy cohort, Journal of Trace Elements in Medicine and Biology. 2018; 45:41-7. Crossref. PMid:29173481.

11. BrbootI MM, AbiD BA, Al-Shuwaki NM. Removal of heavy metals using chemicals precipitation, Engineering and Technology Journal. 2011; 29(3):595-612. 
12. Gaikwad RW, Sapkal VS, Sapkal RS. Ion exchange system design for removal of heavy metals from acid mine drainage wastewater, Acta Montanistica Slovaca. 2010; 15(4):298-304.

13. Mihaly M, Comanescu AF, Rogozea EA, Meghea A. Nonionic microemulsion extraction of $\mathrm{Ni}$ (II) from wastewater, Molecular Crystals and Liquid Crystals. 2010; 523(1):63-72. Crossref.

14. Kozlowski CA, Walkowiak W. Removal of chromium (VI) from aqueous solutions by polymer inclusion membranes, Water Research. 2002; 36(19):4870-6. Crossref.

15. Shaalan HF, Sorour MH, Tewfik SR. Simulation and optimization of a membrane system for chromium recovery from tanning wastes, Desalination. 2001; 141(3):315-24. Crossref.

16. Maximous NN, Nakhla GF, Wan WK. Removal of Heavy Metals from Wastewater by Adsorption and Membrane Processes: a Comparative Study, International Journal of Environmental and Ecological Engineering. 2010; 4(4):594-9.

17. Shi J, Yi S, He H, Long C, Li A. Preparation of nanoscale zero-valent iron supported on chelating resin with nitrogen donor atoms for simultaneous reduction of $\mathrm{Pb} 2+$ and NO3-, Chemical Engineering Journal. 2013; 230:166-71. Crossref.

18. Liguori F, Moreno-Marrodan C, Barbaro P. Metal nanoparticles immobilized on ion-exchange resins: A versatile and effective catalyst platform for sustainable chemistry, Chinese Journal of Catalysis. 2015; 36:1157-69. Crossref.

19. Hackbarth FV, Girardi F, de Souza SMAGU, de Souza AÔAU, Boaventura RAR, Vilar VJP. Marine macroalgae Pelvetia canaliculata (Phaeophyceae) as a natural cation exchanger for cadmium and lead ions separation in aqueous solutions, Chemical Engineering Journal. 2013; 242:294-305. Crossref.
20. Cechinel MAP, Mayer DA, Pozdniakova TA, Mazur LP, Boaventura RAR, de Souza AAU, de Souza SMAGU, Vilar VJP. Removal of metal ions from a petrochemical wastewater using brown macro-algae as natural cation-exchangers, Chemical Engineering Journal. 2016; 286:1-15. Crossref.

21. Bulgariu D, Bulgariu L. Sorption of $\mathrm{Pb}$ (II) onto a mixture of algae waste biomass and anion exchanger resin in a packedbed column, Bioresources Technology. 2013; 129:374-80. Crossref. PMid: 23262014.

22. Al-Wakeel KZ, Abd El Monem H, Khalil MMH. Removal of divalent manganese from aqueous solution using glycine modified chitosan resin, Journal Environmental Chemical Engineering. 2015; 3(1):179-86. Crossref.

23. Demirbas A, Pehlivan E, Gode F, Altun T, Arslan G. Adsorption of $\mathrm{Cu}(\mathrm{II}), \mathrm{Zn}(\mathrm{II}), \mathrm{Ni}(\mathrm{II}), \mathrm{Pb}(\mathrm{II})$, and $\mathrm{Cd}(\mathrm{II})$ from aqueous solution on Amberlite IR-120 synthetic resin, Journal Colloid Interface Science. 2005; 282(1):20-5. Crossref. PMid: 15576076.

24. Hallajiqomi M, Eisazadeh H. Adsorption of manganese ion using polyaniline and it's nanocomposite: Kinetics and isotherm studies, Journal of Industrial and Engineering Chemistry. 2017; 55:191-7. Crossref.

25. Wang X, Guo Y, Yang L, Han M, Zhao J, Cheng X. Nanomaterials as Sorbents to Remove Heavy Metal Ions in Waste Water Treatment, Environmental and Analytical Toxicology. 2012; 2:2-7. Crossref. 